\title{
KASUS KROMOBLASTOMIKOSIS PADA SEORANG PEREMPUAN
}

\author{
Mariani V. Lasut \\ Rita S. Tanamal \\ Grace M. Kapantow
}

\author{
Bagian Ilmu Kesehatan Kulit dan Kelamin \\ Fakultas Kedokteran Universitas Sam Ratulangi Manado \\ Email: riani1603@yahoo.com
}

\begin{abstract}
Chromoblatomycosis is a chronic fungal infection in the skin and subcutaneus tissue caused by pigmented fungi. It occurs most in males in tropical and subtropical countries. The causal fungi were found isolated in woods, decomposed plants, and soil. Early lesions manifest as papules that become hypertrophy plaques, and in years they develop to become hyperkeratotic masses. Chromoblastomycosis is difficult to treat. We reported a female of 37 years with lesions on the right foot for 20 years in the forms of plaques, papulonodules, multiple verrucous lesions. Lesions had hard consistency and were associated with erosion, crustae, and minimal pus. Several supporting tests were carried out. KOH 20\% test resulted in sclerotic bodies; fungal culture revealed Fonsecaea pedrosoi; and histopathological examination showed chronic granulomatous inflamation. The patient was treated with itraconazole 2 x $200 \mathrm{mg}$ daily, which was planned for 8-12 months. After 2 months of treatment, the lesions improved. Conclusion: Based on anamnesis, physical examination, $\mathrm{KOH}$ test, tissue culture, and histopathology examination, this case was diagnosed as chromoblatomycosis. Fonsecaea pedrosoi was found as the causative agent. Oral antimycotic itrakonazole 2 x $200 \mathrm{mg} /$ day showed lesion improvement after 2 months of treatment. The patient will be evaluated until full treatment has been achieved.
\end{abstract}

Keywords: chromoblastomycosis, Fonsecaea pedrosoi, itrakonazole

\begin{abstract}
Abstrak: Kromoblastomikosis merupakan infeksi jamur kronis pada kulit dan jaringan subkutan, disebabkan jamur berpigmen, umumnya pada laki-laki, banyak ditemukan di daerah tropis/subtropis, terisolasi di lingkungan dari kayu, sisa tanaman, dan tanah. Lesi awal berupa papul yang membesar membentuk plak hipertrofi dalam beberapa tahun menjadi massa hiperkeratotik. Kromoblastomikosis sukar disembuhkan. Kami melaporkan seorang perempuan 37 tahun dengan lesi pada kaki kanan sejak 20 tahun lalu berupa plak, papulonodul, verukous multipel, konsistensi keras, disertai erosi, krusta, pus yang minimal. Pada pemeriksaan $\mathrm{KOH} 20 \%$ didapatkan badan sklerotik, pemeriksaan kultur jamur ditemukan Fonsecaea pedrosoi, histopatologis menunjukkan radang kronik granulomatik. Terapi itrakonazole 2x200 mg/hari akan diberikan selama 8-12 bulan. Setelah 2 bulan pengobatan terdapat perbaikan. Simpulan: Pada kasus ini, diagnosis kromoblastomikosis ditegakkan berdasarkan anamnesis, pemeriksaan fisik, dan pemeriksaan penunjang berupa $\mathrm{KOH}$, kultur jaringan, dan histopatologi. Hasil kultur menunjukkan Fonsecaea pedrosoi sebagai penyebab kromoblastomikosis. Pemberian antimikotik oral itrakonazole 2 x 200 mg/hari menunjukkan perbaikan setelah 2 bulan pengobatan. Evaluasi akan terus dilanjutkan sampai pengobatan selesai.
\end{abstract}

Kata kunci: kromoblastomikosis, Fonsecaea pedrosoi, itrakonazole 
Kromoblastomikosis merupakan infeksi jamur kronis pada kulit dan jaringan subkutan yang disebabkan oleh jamur berpigmen atau dematiceous fungi yang menembus kulit. Pada proses inflamasinya di dalam kulit, jamur tersebut membentuk sel tunggal berdinding tebal atau sel kluster (badan sklerotik atau muriform) yang menyerupai gambaran berbentuk hiperplasia pseudoepiteliomatosa. ${ }^{1,2}$ Kejadian kromoblastomikosis ditemukan tersebar di seluruh dunia, namun banyak ditemukan pada daerah tropis dan subtropis di Amerika dan Afrika. ${ }^{2}$ Umumnya penyakit ini menyerang laki-laki dibandingkan perempuan, sering pada usia 30-50 tahun namun beberapa laporan menyebutkan terjadi pada anak-anak dan remaja. ${ }^{3}$ Hingga saat ini dilaporkan 2 kasus kromoblastomikosis di Bagian Ilmu Kesehatan Kulit dan Kelamin RSUP Prof. DR. R. D. Kandou, Manado.

Infeksi kromoblastomikosis dapat disebabkan oleh beberapa jenis jamur berpigmen, yang paling sering antara lain: Phialophora verrucosa, Fonsecaea pedrosoi, Fonsecaea Compactum, Fonsecaea monophora, Wangiella dermatitidis, Cladophialophora carrionii, Rhinocladiella aquaspersa, dan spesies exophiala. Jamur terisolasi di lingkungan dari kayu, sisa-sisa tanaman, atau tanah. ${ }^{1,4,5}$

Gambaran klinis kromoblastomikosis biasanya muncul di area yang terlihat, seperti kaki, tungkai bawah, lengan, wajah, dan leher. ${ }^{6}$ Awalnya muncul berupa papul mirip kutil yang tumbuh makin membesar dan membentuk plak hipertrofi. Pada beberapa lesi, plak muncul dengan permukaan rata dan bertumbuh perlahan dengan skar pada bagian tengah, dan dalam beberapa tahun lesi telah menjadi massa hiperkeratotik dan dapat menebal sampai $3 \mathrm{~cm}$. ${ }^{1,4,6}$

Kromoblastomikosis dapat didiagnosis banding dengan lesi verukous kronis lainnya seperti tuberkulosis kutis verukosa, sehingga dibutuhkan pemeriksaan penunjang seperti kultur jamur dan pemeriksaan histopatologik untuk mengarahkan diagnosis. $^{1}$

Kromoblastomikosis sukar disembuh- kan dan tidak sedikit kasus yang rekalsitran. $^{7}$ Sampai saat ini tidak ada standar khusus untuk penanganan kromoblastomikosis. Dalam beberapa dekade terakhir terdapat beberapa jenis terapi yang dapat digunakan sebagai regimen terapi seperti obat-obatan antifungal sistemik atau intravena, terapi panas, penggunaan cairan nitrogen, pembedahan, serta laser. ${ }^{2,8}$

Berikut ini akan dilaporkan satu kasus kromoblastomikosis di kaki kanan yang disebabkan Fonsecaea pedrosoi pada seorang perempuan berumur 37 tahun yang menunjukkan perbaikan setelah 2 bulan pengobatan.

\section{LAPORAN KASUS}

Seorang perempuan berumur 32 tahun, suku Sangihe, datang ke Poliklinik Kulit dan Kelamin RSUP Prof. Dr. R. D. Kandou pada tanggal 7 November 2013 dengan keluhan timbul benjolan di kaki kanan sejak 20 tahun lalu. Pada awalnya muncul berupa bercak kemerahan di punggung kaki kanan saat penderita hamil, kemudian membengkak dan tidak hilang sampai sekitar 5 tahun kemudian, yang diikuti dengan timbulnya lepuh-lepuh kecil di punggung kaki yang kemudian menjadi luka. Sebagian luka kemudian tumbuh menebal dan menjadi benjolan dengan permukaan kasar yang makin lama makin banyak dan meluas. Benjolan kadangkadang dirasakan gatal dan juga nyeri. Benjolan akan berdarah saat dikupas. Sehari-hari penderita bekerja sebagai petani, dan saat beraktivitas di kebun penderita tidak mengenakan alas kaki. Penderita sering tergores ranting atau rumput tajam saat berkebun dan tidak pernah mengalami luka berat atau dalam yang mengenai kaki selama berkebun. Riwayat sakit kencing manis atau sakit berat lainnya disangkal, riwayat alergi disangkal, dan hanya penderita yang sakit seperti ini dalam keluarga.

Pada pemeriksaaan fisik ditemukan kesadaran kompos mentis. Tekanan darah $120 / 70 \mathrm{mmHg}$, denyut nadi $86 \mathrm{x} / \mathrm{mnt}$, frekuensi napas $20 \mathrm{x} /$ menit, suhu aksila 
$36,5^{\circ} \mathrm{C}$, dan berat badan $47 \mathrm{~kg}$. Kepala normosefali, konjungtiva tidak tampak anemis, sklera tidak ikterik, refleks pupil positif dan isokor. Pada telinga, hidung, tenggorokan tidak ditemukan kelainan. Pemeriksaan jantung dan paru dalam batas normal. Hepar dan lien tidak teraba, bising usus dalam batas normal, tidak terdapat distensi abdomen. Pembesaran kelenjar getah bening tidak ditemukan. Ekstremitas teraba hangat, tidak ditemukan edema.

Pada pemeriksaan dermatologik regio kruris dekstra tampak plak hipertrofi dengan pemukaaan papulonodul verukous, multipel, ukuran bervariasi dari lentikuler sampai plakat dengan konsistensi keras. Terdapat juga erosi, pus minimal, serta krusta (Gambar 1A-C).

Pada pemeriksaan laboratorium sederhana dengan $\mathrm{KOH} \mathrm{20 \%} \mathrm{didapatkan}$ badan sklerotik. Hasil pemeriksaan laboratorium darah didapatkan kadar leukosit yang meningkat menjadi 11.000/uL sedangkan nilai hematologi lain dan elektrolit dalam batas normal. Hasil pemeriksaan kadar Serum Glutamic Oxaloacetic Transaminase (SGOT) dan Serum Glutamic Pyruvate Transaminase (SGPT) dalam batas normal.

Pemeriksaan radiologis toraks memperlihatkan jantung dan paru dalam batas normal. Pemeriksaan radiologis pedis dekstra tidak ditemukan kelainan dan tulang intak. Hasil kultur jaringan menggunakan media Sabouraud dextrose agar (SDA) pada pemeriksaan makroskopik ditemukan koloni filamen warna coklat tua, merah kehitaman, dengan latar belakang merah tua/hijau tua, sedangkan pada pemeriksaan mikroskopik ditemukan hifa bersepta positif, spora coklat tua serta konidia dan hifa tampak warna coklat. Pada slide kultur dengan pemeriksaan mikroskopis ditemukan konidia bercabang bentuk oval menonjol pada ujung hifa, hiperpigmentasi warna coklat dan spora warna coklat (Gambar 2) sehingga disimpulkan Foncesaea Pedrosoi sebagai penyebab kromoblastomikosis, dan terapi antimikotik dapat dipertimbangkan.
Hasil pemeriksaan histopatologik memperlihatkan epidermis yang hiperkeratosis, papilomatosis dan sedikit degenerasi vaskuler. Pada dermis tampak fokus-fokus infiltrat sel-sel radang limfosit, PMN, dan histiosit yang sebagian membentuk granuloma, sehingga disimpulkan adanya radang kronik granulomatik. Gambaran histopatologik demikian dapat ditemukan pada infeksi kromoblastomikosis namun tidak patognomonik (Gambar 3 A-C).

Pemeriksaan kultur pus dengan kuman Pseudomonas aeruginosa dan didapatkan beberapa antibiotik yang resisten yaitu amoxicillin clavulanic acid, ampicillin sulbactam, cefazolin, chloramphenicol, erythromycin, nalidix acid, doxycycline, cefpirome, fosfomycin, serta nitrofurantoin.

Berdasarkan anamnesis, gambaran klinis, dan pemeriksaan penunjang yang dilakukan maka kasus ini didiagnosis sebagai kromoblastomikosis yang disebabkan Fonsecaea pedrosoi. Pengobatan yang diberikan berupa antimikotik oral itrakonazole 2x200 mg per hari, perawatan luka dengan kompres cairan Nacl 0,9\%, dan pemberian topikal asam fusidat pada luka, juga diberikan terapi simptomatis untuk mengurangi nyeri. Setelah 2 bulan (hari ke-77) pengobatan tampak perbaikan lesi secara klinis (Gambar 4 A-C).

\section{BAHASAN}

Kromoblastomikosis, atau kromomikosis, merupakan infeksi jamur kronis pada jaringan kutis dan subkutis. Seperti halnya mikosis subkutan lainnya terjadinya infeksi jamur ini disebabkan oleh adanya elemen jamur yang masuk ke dalam kulit melalui luka. Lesi berawal pada area inokulasi dan berkem-bang dalam beberapa bulan sampai beberapa tahun kemudian.,6 Berdasarkan anamnesis pada pasien ini didapatkan adanya riwayat berulang tergores ranting atau rumput tajam saat berkebun dan sekitar 20 tahun lalu muncul bercak kemerahan di punggung kaki kanan yang kemudian berkembang menjadi benjolan di kaki kanan. 

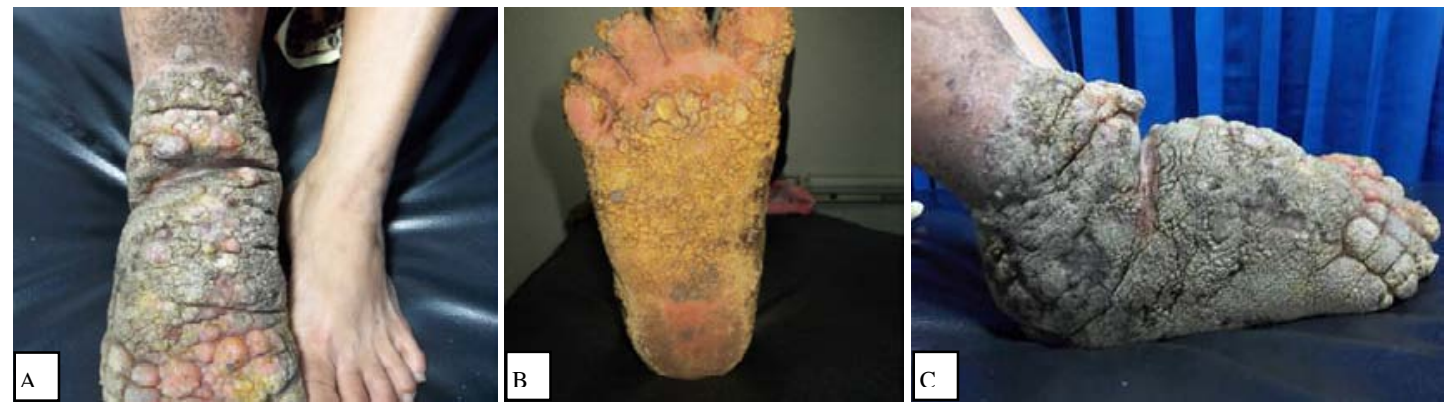

Gambar 1. Sebelum pemberian itraconazole 2 x $200 \mathrm{mg} / \mathrm{hari}$
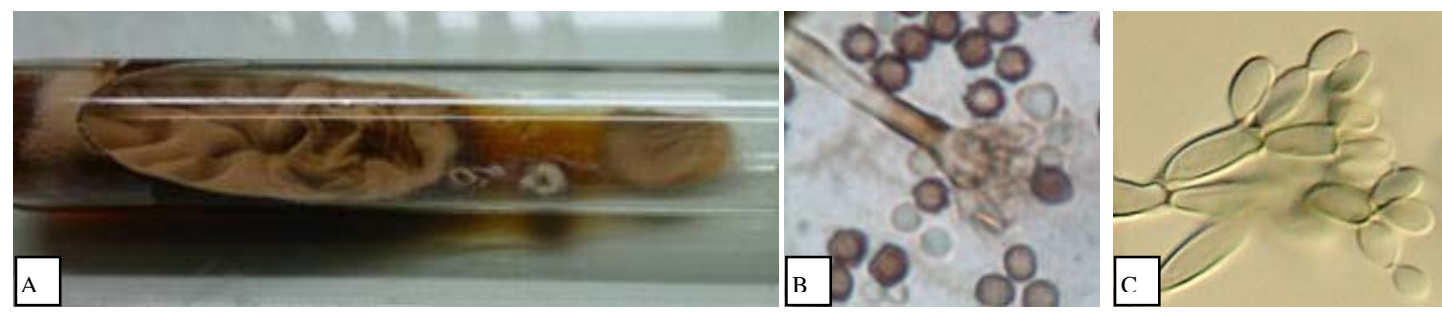

Gambar 2. A, Hasil kultur jaringan menggunakan media Sabouraud dextrose agar pada pemeriksaan makroskopik ditemukan koloni filamen warna coklat tua, merah kehitaman, dengan latar belakang merah tua/hijau tua. B, Mikroskopik tampak hifa bersepta positif, spora coklat tua, serta konidia dan hifa berwarna coklat. C, Mikroskopik slide kultur ditemukan konidia bercabang bentuk oval menonjol pada ujung hifa, hiperpigmentasi warna coklat dan spora warna coklat.
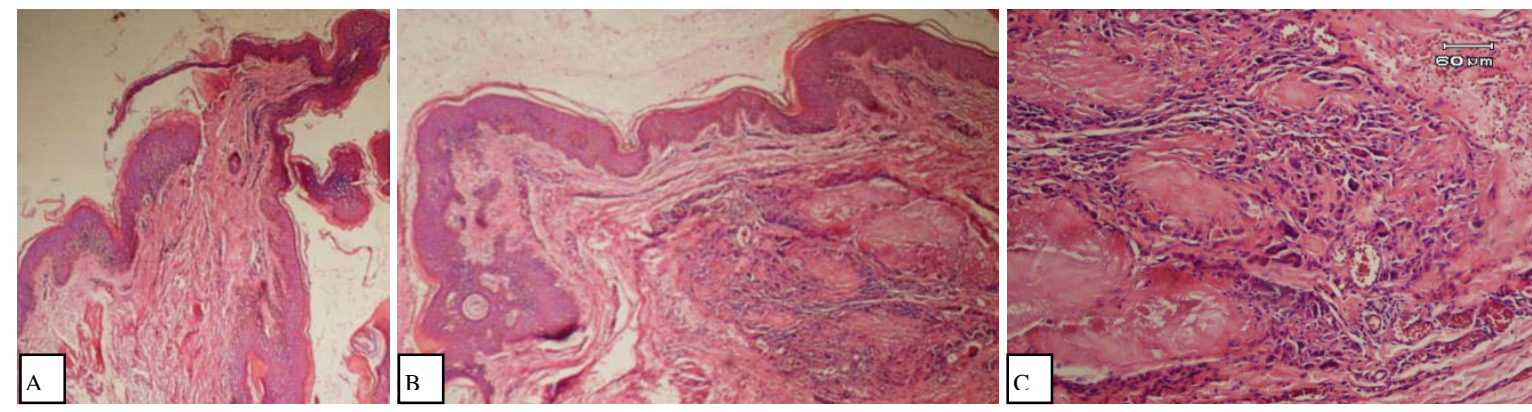

Gambar 3. A dan B, Epidermis yang hiperkeratosis, papilomatosis, dan sedikit degenerasi vaskuler. C, Pada dermis tampak fokus-fokus infiltrat sel-sel radang limfosit, PMN, dan histiosit yang sebagian membentuk granuloma
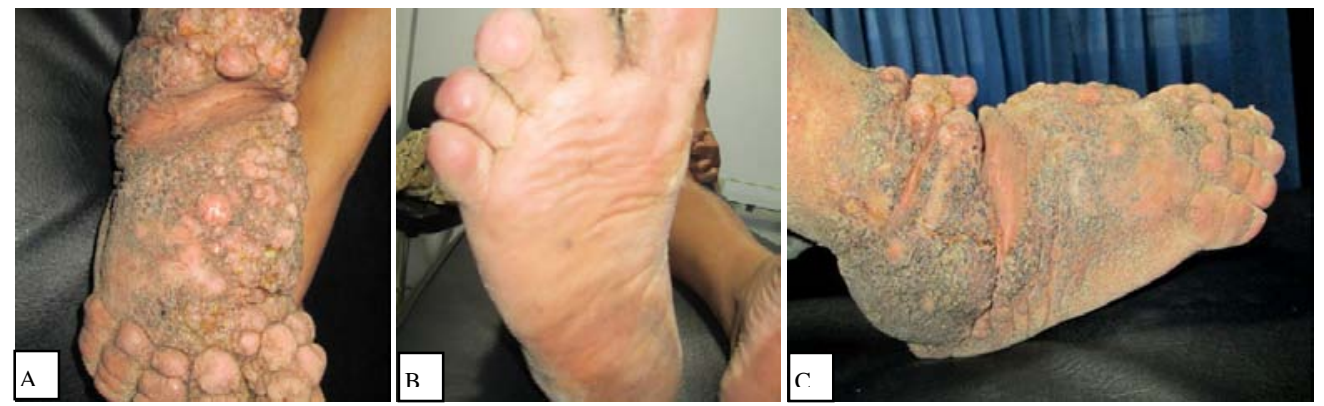

Gambar 4. Setelah pemberian itraconazole 2 x 200 mg/hari selama 77 hari 
Umumnya kromoblastomikosis lebih sering terjadi pada laki-laki dibandingkan perempuan dan pada usia 30-50 tahun namun terdapat beberapa laporan kasus yang terjadi pada usia anak. ${ }^{3}$ Pada penelitian yang dilakukan oleh Minotto et al di Brazil $(2001)^{9}$ dari 100 kasus kromoblastomikosis didapatkan $72 \%$ sebagai pekerja di bidang pertanian dan 78\% pada laki-laki. Walaupun kasus yang dilaporkan ini seorang perempuan berusia 37 tahun tetapi pekerjaan sehari-harinya sebagai petani yang bekerja di kebun.

Lesi kromoblastomikosis yang tumbuh di permukaan kulit biasanya ditemukan di ekstremitas bagian bawah, namun dapat juga pada bagian tubuh lainnya seperti lengan, badan, dan wajah walaupun jarang. ${ }^{10-12}$ Di India, Chandran et al (2012) melaporkan 35 kasus kromoblastomikosis dimana 21 kasus pada badan bagian bawah, 11 kasus pada badan bagian atas, 3 kasus pada dada/punggung. Pada 24 kasus ditemukan keluhan asimtomatis, dan sisanya sekitar 11 kasus mengalami gatal, nyeri, atau keduanya. ${ }^{13}$ Lesi awal dapat muncul setelah adanya trauma pada kulit dari material vegetatif berupa papul kemerahan yang melebar secara perlahan dalam hitungan bulan sampai tahunan dan kemudian menjadi bentuk nodular atau plak. ${ }^{1}$ Lesi menyebar pada bagian lateral ke daerah kulit yang sehat dan biasanya akan tampak gambaran seperti kembang kol (cauliflower like) yang menyebar secara perlahan dan terlokalisir. Tipe plak yang lebih rata menyebar pada bagian tepi, yang ditunjukkan dengan tepi aktif meninggi dan meninggalkan area sentral yang tidak aktif. $^{4,14}$ Pada kasus ini lesi kromoblastomikosis tumbuh di ekstremitas bawah dan kadang disertai dengan rasa gatal dan nyeri. Awalnya lesi hanya muncul di punggung kaki kanan dan kemudian makin meluas menyerang kulit yang masih sehat disekitarnya. Bagian tepi terlihat lebih meninggi dibandingkan bagian tengah lesi.

Aspek klinis dari kromoblastomikosis beragam. Pada pasien yang sama dapat ditemukan 2 atau lebih bentuk klinis, yaitu:
1) lesi nodular dengan permukaan

menonjol yang ditutupi dengan gambaran kembang kol; 2) lesi tumor yang luas; 3) lesi hiperkeratotik verukous yang luas dan ireguler; 4) kemerahan, datar, dan papul bersisik; serta 5) lesi jaringan parut atrofi dengan bagian tengah tidak aktif. ${ }^{15}$ Penyebaran lesi dapat disebabkan karena hasil autoinokulasi dari menggaruk. ${ }^{2}$ Pada kasus ini bentuk klinis yang tampak yaitu gambaran kembang kol dan lesi hiperkeratotik verukous yang luas dan ireguler.

Dari hasil anamnesis didapatkan penderita jarang mengenakan alas kaki saat berkebun sehingga sering terkena trauma ringan seperti lecet atau tetusuk ranting pohon dan rumput liar, namun pasien menyangkal pernah mengalami trauma atau menderita luka yang dalam atau berat. Keluhan sudah muncul sejak sekitar 20 tahun lalu, diawali dengan muncul bercak kemerahan serta bengkak pada kaki kanan dan kemudian muncul lepuh-lepuh yang pecah, menjadi luka, dan menebal dengan tonjolan-tonjolan yang permukaannya kasar dan makin luas dalam beberapa tahun terakhir. Penderita juga mengeluhkan adanya nyeri dan gatal yang kadang-kadang muncul. Pada pemeriksaan dermatologis regio pedis dekstra didapatkan plak verukous, ukuran lentikuler sampai plakat, konsistensi keras, permukaan verukous dengan erosi, pus dan krusta.

Kromoblastomikosis harus dibedakan dari tuberkulosis kutis verukosa dan keganasan kulit lainnya sehingga dibutuhkan pemeriksaan penunjang lainnya untuk mendukung diagnosis pasti. ${ }^{4,6}$ Kasus ini diberikan diagnosis banding dengan tuberkulosis kutis verukosa karena gambaran klinis yang muncul berupa lesi hiperkeratotik dengan permukaan verukous yang luas dan ireguler.

Pemeriksaan penunjang untuk kromoblastomikosis antara lain: pemeriksaan laboratorium darah, pemeriksaan laboratorium sederhana dengan mikroskopik langsung, histopatologik, dan pemeriksaan kultur jamur. ${ }^{2}$ Hasil pemeriksaan laboratorium darah pada kasus ini dalam batas normal termasuk pemeriksaan fungsi hati dimana pada pemberian antimikosis oral 
butuh pengawasan fungsi hati. Pemeriksaan radiologis toraks menunjukkan jantung dan paru dalam batas normal. Pemeriksaan radiologis pedis dekstra didapatkan hasil normal dan tulang dalam keadaan intak.

Pemeriksaan mikroskopik langsung dengan $\mathrm{KOH} 10 \%$ atau 20\% pada kerokan kulit akan memperlihatkan badan medlar yang biasa dikenal sebagai badan sklerotik/sel muriform atau copper pennies, yang kecil, bulat, dan warna kecoklatan. ${ }^{5}$ Pada kasus ini pemeriksaan dilakukan dengan menggunakan $\mathrm{KOH} 20 \%$ dan didapatkan hasil adanya badan sklerotik/sel muriform.

Pemeriksaan histopatologik dengan pewarnaan hematoxylin eosin (HE) pada kromoblastomikosis akan tampak gambaran granuloma inflamasi berupa hiperplasia epidermal pseudoepiteliomatous dengan parakeratosis, spongiosis, dan infiltrat dermal ekstensif yang terdiri dari histiosit epitelioid yang banyak. Komponen lain dari infiltrat yaitu adanya multinucleated giant cells dimana di dalamnya terdapat badan sklerotik, netrofil, limfosit, sel plasma, dan eosinofil. ${ }^{16}$ Pada kasus ini didapatkan hasil pemeriksaan histopatologik berupa jaringan kulit dengan epidermis yang hiperkeratosis, papilomatosis dan sedikit degenerasi vaskuler. Pada dermis tampak fokus-fokus infiltrat sel radang limfosit, PMN dan histiosit yang sebagian membentuk granuloma dengan simpulan radang kronik granulomatik. Gambaran histopatologik demikian dapat ditemukan pada infeksi kromoblastomikosis namun tidak patognomonik.

Spesies jamur penyebab kromoblastomikosis tidak dapat dibedakan dari pemeriksaan histopatologik sehingga diperlukan identifikasi kultur jaringan. Secara makroskopik, hasil kultur jaringan dari jamur umumnya memberikan gambaran yang hampir sama yaitu koloni kehitaman. Identifikasi kultur secara mikroskopik bergantung pada adanya perbedaan tipe sporulasi. Diferensiasi yang akurat dari berbagai jamur cukup sulit untuk dilakukan. ${ }^{1}$ Pemeriksaan kultur jamur dari kerokan kulit atau jaringan biopsi harus dilakukan pada SDA. Umumnya jamur tumbuh dalam 10-14 hari dan tampak seperti koloni beludru dengan warna hijau tua dan kemudian akan menjadi hitam. Pada gambaran mikroskopik akan tampak hifa dematiseus dengan septa, bercabang dan konidia. ${ }^{15,17,18}$ Pada kasus ini dilakukan kultur jaringan dengan SDA yang ditambahkan chloramphenicol, dievaluasi setelah 14 hari, dan didapatkan hasil secara makroskopik koloni filamen warna coklat tua, merah kehitaman dengan latar belakang merah tua/hijau tua. Pada gambaran mikroskopik tampak hifa bersepta positif, spora coklat tua, serta konidia dan hifa berwarna coklat. Pada kultur slide secara mikroskopik tampak konidia bercabang bentuk oval menonjol pada ujung hifa, hiperpigmentasi berwarna coklat dengan spora berwarna coklat yang merupakan gambaran Fonsecaea pedrosoi (penyebab kromoblastomikosis) sehingga kasus ini didiagnosis pasti sebagai kromoblastomikosis yang disebabkan Fonsecaea pedrosoi.

Terdapat beberapa pilihan terapi yang dapat digunakan untuk kromoblastomikosis yaitu itrakonazole 100-400 mg/hari yang digunakan dalam periode lama, biasanya selama 8-12 bulan bahkan lebih lama. Selain itu, juga ada pilihan terapi terbinafin $250 \mathrm{mg}$ setiap hari, fluconazole 200-600 $\mathrm{mg} /$ hari, thiabendazole $25 \mathrm{mg} /$ hari yang dibagi dalam 3 dosis, ketokonazole 200$400 \mathrm{mg} / \mathrm{hari}$, saperconazole, dan pada lesi yang luas dapat digunakan intravena amphotericin B (sampai $1 \mathrm{mg} / \mathrm{kg}$ setiap hari). ${ }^{1,4,15,19}$ Seluruh agen terapi ini dihubungkan dengan efek yang dapat merugikan pasien sehingga dibutuhkan monitoring fungsi hati dan ginjal. Di daerah endemik, pada kasus dengan terapi intravena amphotericin B dapat diminimalisasi dengan penggunaan formulasi liposomal walaupun harganya cukup mahal. ${ }^{15}$ Kumpulan senyawa dari golongan azole bekerja secara in vitro dan in vivo pada beberapa infeksi jamur, termasuk agen kromoblastomikosis. $^{8}$ Aktivitas anti jamur itrakonazole lebih lebar dan efek samping 
yang ditimbulkannya lebih kecil dibandingkan dengan ketoconazole. Itrakonazole diserap lebih sempurna melalui saluran cerna bila diberikan bersama makanan. Seperti golongan azole lainnya, itrakonazole juga berinteraksi dengan enzim mikrosom hati tetapi tidak sebanyak ketoconazole. ${ }^{2,8}$ Pada kasus ini penderita diberikan terapi itrakonazole 2x200 mg per hari, perawatan luka dengan kompres cairan Nacl 0,9\%, dan pemberian topikal asam fusidat pada luka, serta terapi simptomatis untuk mengurangi nyeri. Sebelumnya pada penderita ini sudah dilakukan pemeriksaan fungsi hati dan ginjal dengan hasil dalam batas normal sehingga efek samping pemberian antifungal sistemik dapat diminimalisasi. Pengobatan dengan itrakonazole direncanakan selama 8-12 bulan. Setelah pengobatan bulan ke-2 mulai tampak perbaikan secara klinis. Evaluasi akan terus dilakukan sampai pengobatan selesai.

Pembedahan dapat menjadi pilihan jika lesi kecil, karena dapat berisiko diseminasi lokal yang tinggi dan harus disertai dengan pengobatan anti jamur. Beberapa acuan pustaka juga menyebutkan pilihan terapi lain yaitu pembedahan laser dengan karbon dioksida, bedah Mohs, kuretase menggunakan elektrokauter, terapi panas, serta cryotherapy dengan nitrogen cair. Kombinasi antara pembedahan dengan antifungal sistemik dikatakan dapat memberikan hasil yang memuaskan; begitu pula dengan kombinasi dari beberapa agen antifungal sistemik. ${ }^{2,8,15,19,20}$ Pada kasus ini hanya diberikan antifungal sistemik itrakonazole; jika hasil masih belum memuaskan maka akan dipertimbangkan untuk pemberian kombinasi antifungal sistemik. Terapi harus dilanjutkan sampai ada resolusi klinis, yang biasanya membutuhkan beberapa bulan terapi. Relaps mungkin terjadi terutama pada lesi yang luas. Untuk keberhasilan terapi pada kasus kromoblastomikosis perlu diperhatikan mengenai kesehatan secara umum dari penderita, kondisi sosio-ekonomi, kepatuhan terhadap terapi, serta pengobatan penyakit penyerta dan komplikasi. Pada beberapa kasus dilaporkan terapi yang gagal mungkin diakibatkan kepatuhan pasien untuk minum obat yang kurang karena durasi pengobatan yang lama, atau karena sebagian besar kasus dengan pekerjaan petani dan tinggal cukup jauh dari pusat layanan kesehatan. ${ }^{8,15,20}$ Prognosis kasus ini quo ad vitam ad bonam, quo ad functionam, dan quo ad sanationam ialah dubia ad bonam.

\section{SIMPULAN}

Telah dilaporkan seorang perempuan berusia 37 tahun dengan lesi pada kaki kanan sejak 20 tahun lalu berupa plak, papulonodul verukous multipel, konsistensi keras disertai erosi, krusta, pus minimal. Pada pemeriksaan $\mathrm{KOH} 20 \%$ didapatkan badan sklerotik, pada pemeriksaan kultur jamur ditemukan Fonsecaea pedrosoi, pemeriksaan histopatologik menunjukkan radang kronik granulomatik. Berdasarkan hasil pemeriksaan di atas maka diagnosis yang ditegakkan ialah kromoblastomikosis. Pengobatan yang diberikan ialah itrakonazole 2x200 mg/hari yang direncanakan selama 8-12 bulan. Evaluasi setelah 2 bulan pengobatan sudah memperlihatkan perbaikan.

\section{DAFTAR PUSTAKA}

1. Hay RJ. Deep fungal infections. In: Goldsmith LA, Katz SI, Gilchrest, Paller AS, Leffell DJ, Wolff K, editors. Fitzpatrick's Dermatology in General Medicine (8th ed). New York: McGraw Hill, 2012; p. 1833-35.

2. Baddley JW, Dismukes WE. Chromoblastomycosis. In: Kauffman CA, Pappas PG, Sobel JD, Dismukes WE, editors. Essential of Clinical Mycology (2nd ed). New York: Springer Science-Business Media, 2011; p. 427-31.

3. Angadi KM, Misra RN, Gandham NR, Moumita S, Vyawahare, Singhania SS, et al. Chromoblastomycosis: a rare case of infection by Fonsecaea compacta from western Maharashtra, India. International Journal of Microbiology Research. 2012;4(9): 330-1. 
4. Sober JO, Elewski BE. Fungal diseases. In: Bolognia JL, Jorizzo JL, Rapini RP, editors. Dermatology (2nd ed). Spanyol: Mosby, 2008; p. 1150.

5. Roy AD, Das D, Deka M. Chromoblastomycosis a clinical mimic of squamous carcinoma. Australian Medical Journal. 2013;6(9):458-60.

6. Hay RJ, Ashbee HR. Mycology. In: Burns T, Breathnach S, Cox N, Griffiths C, editors. Rook's Textbook of Dermatology (8th ed). Oxford: Blackwell Publishing; 2010. p. 36.75-6.

7. Buot G, Bachmeyer C, Benazeraf C, Bourat E, Garrely EB, Binnet 0 . Chromoblastomycosis: an unusual diagnosis in Europe. Acta Derm Venereal. 2004;85:259-60.

8. Esterre P, Queiroz-Telles F. Management of chromoblastomycosis: novel perspectives. Curr Opin Infect Dis. 2006;9:148-152.

9. Minotto R, Bernardi CDV, Mallmann LF, Edelweiss MIA, Scroferneker ML. Chromoblastomycosis: A review of 100 cases in the state of Rio Grande do Sul, Brazil. J Am Acad Dermatol. 2001;44:585-92.

10.Pradeepkumar NS, Joseph NM. Chromoblastomycosis caused by Cladophialophora carrionii in a child from India. $\mathrm{J}$ Infect Dev Ctries. 2011;5(7):556-60.

11.Bhagwat PV, Tophakhane RS, Kudligi S, Noronha T. Multiple asymptomatic verrucous plaques over the legs. Indian Journal of Dermatology, Venereology and Leprosy. 2010;76(1):86-8.

12.Khan I, Khan RA, Khan SM. Clinicopathological study of cutaneous chromoblastomycosis in Pakistan. Journal of Pakistan Association of Dermatologists. 2012;22:122-5.
13.Chandran V, Sadanandan SM, Sobhanakumari. Chromoblastomycosis in Kerala, India. Indian Journal of Dermatology, Venerology, and Leprology. 2012;78:728-33.

14.Ramraje SN, Gakhale J. Cutaneous chromoblastomycosis. Journal of Case Reports. 2013; 3(2):286-90.

15.Martínez RL, Tovar LJM. Chromoblastomycosis. Clinics in Dermatology. 2007;25:188-94.

16.Hinshaw M, Longley JB. Fungal diseases. In: Elder DE, Elenitsas R, Johnson BL, Murphy GF, editors. Lever's Histopathology of the Skin (9th ed). Philadelphia: Williams \& Wilkins, 2005; p. 619-20.

17.Santos ALS, Palmeira VF, Rozental S, Kneipp LF, Nimritcher L, Alviano DS, et al. Biology and pathogenesis of Fonsecaea pedrosoi, the major etiologic agent of chromoblastomycosis. FEMS Microbiol Rev. 2007;31(5):570-591.

18.Zhang J, Xi L, Lu C, Li X, Xie T, Zhang $\mathbf{H}$, et al. Successful treatment for chromoblastomycosis caused by Fonsecaea monophora: a report of three cases in Guangdong, China. Journal compilation. Mycoses. 2008;52:176-81.

19.Ranawaka RR, Amarasinghe N, Hewage D. Chromoblastomycosis: combined treatment with pulsed itraconazole therapy and liquid nitrogen cryotherapy. International Journal of Dermatology. 2009;48:397-400.

20.Huang CF, Chen JF, Wu BY, Chiang CP, Wang WM. Sporotrichoid chromoblastomycosis successfully treated by combinative therapy with systemic oral antifungal agent and topical cryotherapy. J Med Sci. 2011;31(1):51-5. 